Matgorzata Zduniak-Wiktorowicz

Uniwersytet im. Adama Mickiewicza w Poznaniu

\title{
O systemach wartości, zaangażowaniu i objaśnianiu Niemcom kryzysowej Polski przez polsko-niemieckie pisarki z Berlina: Brygidę Helbig-Mischewski i Emilię Smechowski
}

„Kto bezmyślnie beszta Polskę, najwyraźniej niewiele zrozumiał” roku Brygida Helbig-Mischewski komentowała w niemieckiej prasie nową sytuację polityczno-społeczną w Polsce (Helbig-Mischewski 2016). Kilka lat później, w efekcie rocznego pobytu w Gdańsku, Emilia Smechowski wydała w Niemczech literacki i autobiograficzny reportaż pt. Rückkehr nach Polen. Expeditionen in mein Heimatland (Powrót do Polski. Ekspedycja do kraju rodzinnego; Smechowski 2019). Starała się nim niwelować poznawcze napięcia Niemców, które wynikają z trudności ze zrozumieniem zmian zachodzących w Polsce, czyli u ich wschodnich sąsiadów.

$\mathrm{W}$ artykule proponuję prześledzenie motywacji i sposobów pisarskiego zaangażowania obu autorek i w relacje niemiecko-polskie, i w dyskurs im towarzyszący. Twórczość Helbig i Smechowski oraz ich aktywność w przestrzeni publicznej w obu krajach (zabieranie głosu w największych mediach) pozostają bowiem w ścisłym związku z okołobrexitowym kryzysem wartości w Europie, jaki interesuje nas w tym specjalnym numerze „Porównań”.

Oba przywołane wystąpienia - tak będę je w tym tekście traktować - łączy kilka aspektów zewnątrzliterackich. Po pierwsze, autorki należą do grupy polsko-niemieckich/niemiecko-polskich pisarzy migracyjnych, ale reprezentują

1 Tytuł pochodził od redakcji tygodnika „Die Zeit”. 
różne pokolenia: Helbig-Mischewski urodziła się w 1963 roku w Szczecinie i do Niemiec emigrowała jako młoda kobieta zaraz na początku lat osiemdziesiątych xx wieku. Młodsza o 20 lat Smechowski pochodzi z Wejherowa, które opuszczała z rodzicami w roku 1988. Obie od lat mieszkają i działają w Berlinie: Helbig (jako pisarka używa pierwszego członu nazwiska) udziela się m.in. w radiu cosmo, które jest lokalnym programem Westdeutsche Rundfunk i codziennie po 20.00 nadaje audycję po polsku. Oprócz tego prowadzi też np. środowiskotwórcze spotkania autorskie w znanej w Berlinie-Neuköln niemiecko-polskiej księgarni Buchbund. Smechowski z kolei jest dziennikarką, była m.in. redaktorką weekendowego wydania berlińskiej „Die Tageszeitung”, obecnie publikuje jako freelancerka m.in. dla „Süddeutschezeitung” i „Die Zeit”. Za swoją działalność obydwie są doceniane. Dość powiedzieć, że w 2014 roku powieść Niebko Helbig, ten ważny przykład „narracji polsko-niemieckiej” (Iwasiów 2014), znalazła się w finale Literackiej Nagrody Nike. Z kolei za tekst o niewidzialnych w Niemczech Polakach Ich bin wer, den du nicht siehst (Jestem tym, którego nie widzisz, 2015) opublikowany w „TAZ am Wochenende” Smechowski została w 2016 roku wyróżniona m.in. Niemiecką Nagrodą Reporterów i Polsko-Niemiecką Nagrodą Dziennikarską im. Tadeusza Mazowieckiego.

Niezależnie od pokoleniowych różnic, a co za tym idzie odmiennych literackich dykcji (Helbig-Mischewski, Zduniak-Wiktorowicz 2016), aktywność Helbig i Smechowski wykazuje cechy wspólne: obie żywo reagują na te współczesne nam zjawiska, jakie wiążą się z polskością i niemieckością. Ta wspólna płaszczyzna zachęca, by przyjrzeć się im w tym miejscu w tandemie. Jeśli przyjmiemy, że polskość to narracja kulturowa, która w kontakcie z jej sąsiadką niemieckością lubi a to stroić się w znoszone piórka strażniczki przebrzmiałych wartości, a to zaskakiwać zapałem neofitki (odtwarzam tu maksymalnie skrótowo dyskursy, jakie tematowi polskiemu towarzyszą w ostatnich latach w Niemczech, ale też nie są obce naszym krajowym opowieściom), łatwo będzie zauważyć, że obie te narracje wciąż stanowią dla siebie wyzwanie; nie są ani oczywiste, ani letnie. Interesujące mnie w tym artykule wystąpienia autorek pokazują, że polskość i niemieckość mają sobie nawzajem wiele do opowiedzenia - szczególnie gdy chodzi o współczesność: o przeobrażenia tożsamości polskiej i niemieckiej, a wreszcie z mozołem powstającej tożsamości europejskiej. Jak wiadomo, na kształt tej ostatniej znacząco wpływały i wpływają wciąż nowe kryzysy.

\section{Normalność i kryzys(y)}

To kryzys stanowi kolejny zwornik wystąpień Helbig i Smechowski. Jak pisze jeden z badaczy rozlanego dziś nie tylko na Europę kryzysu, stawianie diagnoz 
nosi wyraźne znamiona polityczności: „Ten, kto mówi lub pisze o kryzysie, chce zachęcić do działania, bo sytuacja zrobiła się nie do zniesienia”2 (Brömmel, König, Sicking 2015: 23). W interesującym nas przypadku chodzi o kryzys wartości, związany ze zmianami politycznymi w Polsce, który od 2015 roku osłabia - jak chcą jedni - lub też wzmacnia - jak mówi druga strona polskiego konfliktu fundamenty demokracji. Oczywiście nie jest to wyłącznie sprawa polska, kryzys demokracji diagnozowany jest często w odniesieniu do wielu krajów i wspólnot w Europie, co znacznie utrudnia pisanie o kolejnych jego odmianach:

Co jeszcze należałoby dodać do tych kilometrów opracowań, w których analizowano już instytucje europejskie, wzajemne oddziaływania tych instytucji, relacje między UE a państwami narodowymi albo raz ukradkowe, innym razem ostentacyjne odwracanie się obywateli Europy od demokratycznych instytucji? Punkty ciężkości tych diagnoz bywają różne: kto jest tym złym albo co należy zaliczyć do strukturalnych wad danego rozwiązania, ale fakt, że mamy do czynienia z kryzysem i że dotyczy on demokracji - zarówno z perspektywy krajowej, jak i europejskiej - to powszechne przekonanie (Thiel 2015: 101).

W dyskursie stosunków niemiecko-polskich/polsko-niemieckich kryzys stanowi stale powracający temat, przy czym w nowszej literaturze przedmiotu widać w tym zakresie pewien charakterystyczny dwugłos. Ilekroć historycy i politolodzy w licznych publikacjach diagnozują stan sąsiedztwa, wzmacniają charakterystyczną narrację naukową, zawsze wymieniane są dobrosąsiedzkie osiągnięcia ramowe (traktaty, porozumienia, ważne spotkania władz i notabli, rocznice i „dyplomacja symboli”), osiągnięcia oddolne (współpraca przygraniczna, środowiskowa, naukowa), ale w ślad za nimi idzie enumeracja kolejnych trudności, coraz to nowych drażliwych tematów, różnic w podejściu obu stron do problemu. Do najważniejszych w ubiegłej dekadzie zaliczano m.in. budowę Centrum przeciwko Wypędzeniom w Berlinie, założenie Powiernictwa Pruskiego w odpowiedzi na działania Fundacji Polsko-Niemieckie Pojednanie, stosunek do wojny w Iraku czy budowę niemiecko-rosyjskiego rurociągu omijającego Polskę. Na ogół fakty te badacze komentują bardzo rzeczowo i sucho, ale nawet w tekstach naukowych nieodmiennie słychać ubolewanie, czasem rozczarowanie biegiem spraw i niepewność, jak będzie w przyszłości. Jak mantra wraca też konstatacja, że przecież „było już dobrze”. Dlaczego?

2 Tłumaczenia cytatów z języka niemieckiego są mojego autorstwa. 
Otóż kolejnym ważnym dla naszych rozważań elementem polsko-niemieckiego/niemiecko-polskiego dyskursu jest narracja progresywistyczna, na tle której kolejne kryzysy wypadają bardzo wyraziście. Narracja ta bowiem od bardzo dawna kształtowała stosunki sąsiedzkie w duchu szeroko pojętej "normalizacji” - począwszy od lat dziewięćdziesiątych xx wieku i Traktatu między Rzecząpospolitą Polską a Republiką Federalną Niemiec o dobrym sąsiedztwie i przyjaznej współpracy, przez dykcję z mozołem wypracowanego partnerstwa, naruszanego kolejnymi pomniejszymi kryzysami na przełomie xx i xxı wieku, aż do dwuznacznego zobojętnienia sprzed kilkunastu lat. Przy jednej z bilateralnych okazji tak o obojętnej normalności pisał Basil Kerski:

Dziesiątą rocznicę traktatu dobrosąsiedzkiego w czerwcu 2001 roku przyjęto w polskich mediach raczej ozięble, zaś w Niemczech z dużą obojętnością. Ten brak zainteresowania można uznać za sygnał normalizacji stosunków polsko-niemieckich albo za sygnał ich ochłodzenia (Kerski 2002).

W opinii dyrektora Europejskiego Centrum Solidarności pobrzmiewa obiegowe przekonanie, że jeśli się czymś nie interesujemy, to dlatego, że to coś już znormalniało i spowszedniało. $Z$ drugiej jednak strony brak zainteresowania może być przecież manifestem negatywnego stosunku: wszak okazując brak zainteresowania, wyrażamy też swoje rozczarowanie. Według mnie ten stan sąsiedzkiego dyskursu najlepiej pokazuje, że normalizacja nie była procesem zakończonym - np. wbrew opinii Krzysztofa Ruchniewicza, który przekonywał, iż normalizacja w kontekście stosunków polsko-niemieckich to termin historyczny (Ruchniewicz 2003: 108). Określenie to nadal pojawia się w refleksji naukowej (np. Normalizacja stosunków polsko-niemieckich - proces wciąż trwający?; Bielawska 2009) i niczym słowo-klucz wciąż na nowo paradoksalnie otwiera to, co niezamknięte.

Co normalizujemy przez te wszystkie lata? W myślowym otoczeniu, jakie stanowią Polska i Niemcy, nienormalne oznacza wzajemną niechęć, wrogość, przemoc, agresję, strach, podporządkowywanie siłą, kolonizowanie ziem i umysłów, okupację, odwet, resentyment, stereotypy, kompleksy i samokolonizację: postrzeganie siebie jako wiecznych ofiar. Bardzo wiele z tego, co tworzy repertuar nienormalności, pochodziło więc od „partnera”, który w nowym układzie politycznym po rozpadzie wschodniego imperium stał się przyjmującym do swojego lepszego świata. Do tego wątku jeszcze powrócę. 


\section{Polska europejskość}

Zanim zajrzymy do tekstów Smechowski i Helbig, żeby sprawdzić, jakież to rozchwianie zajmuje autorki, jak postrzegają konfliktową sytuację i swoją w niej rolę, prześledźmy kilka dyskursywnych kontekstów kryzysu jako zjawiska kształtującego naszą sąsiedzką i europejską współczesność.

We wstępie do monografii Europa, wie weiter? Perspektiven eines Projekts in der Kriese (Europo, co dalej? Perspektywy projektu w kryzysie) politolodzy Winfried Brömmel, Helmut König i Manfred Sicking pisali kilka lat temu:

Od dekady proces integracji europejskiej nie tylko tkwi w martwym punkcie, ale jest zwalczany i kwestionowany w zupełnie nowy sposób. Dziś nikt nie potrafi przewidzieć, jak się sprawy potoczą. Niepewność jest wielka, nawarstwiają się wewnętrzne i zewnętrzne wyzwania, brakuje zaufania. Od 2008 roku konflikty, niepokoje i dyskomfort wywoływane są przez kryzys finansowy, bankowy i zadłużeniowy, którego nie da się w żaden sposób przezwyciężyć. Jeszcze wcześniej Traktat Konstytucyjny odrzuciły w referendach Francja i Holandia. Pokazało to dobitnie, jak daleko od wyobrażeń wyborców są ambitne plany elit politycznych (Brömmel, König, Sicking 2015: 7).

Mimo wielu bez wątpienia obiektywnych trudności opisywana wyżej dekada (lata 2007-2017), która upłynęła w atmosferze „Finanzstress in Europa” (Liebert 2019: 39), miała w kontekście Polski i Niemiec zaskakująco rozbieżne skutki, gdy idzie o poczucie europejskiej wspólnoty. W swojej książce poświęconej realnej wizji Europy w XxI wieku, opatrzonej wymownym tytułem Europa erneuern! (Odnowić Europę!), Urlike Liebert przekonuje, że w przypadku Niemiec poziom spójności z UE pozostał na tym samym poziomie, a subiektywnie nawet wzrósł. Natomiast „spójność Polski z UE znacznie poprawiła się strukturalnie, ale pozostała subiektywnie słaba" (Liebert 2019: 35). Potwierdzeniem tego stanu rzeczy mogą być kolejne kryzysy, na czele z szeroko aktualnie dyskutowanym kryzysem demokracji energicznie osłabianej populizmami. Do przyczyn nośności głosów populistów w wielu krajach Unii badacze zaliczają m.in. skutki gęstniejącej pajęczyny utkanej z dyktowanych przez unijnych prawników norm wszelkiego typu. Autor tej przyrodniczo-prawnej metafory pisze: „Dziś, kiedy zapalamy papierosa, kupujemy karton mleka czy rybę, jemy banana albo lody, my (lub produkty, które cenimy) podlegamy europejskim normom" (Stolleis 2015: 179).

Między innymi ten fakt, że wyśrubowana „wspólnota prawna” była nazbyt optymistycznym programem urzędników, bynajmniej niespójnym z możliwościami i potrzebami obywateli poszczególnych unijnych państw, przyczynił 
się do powstania żyznego podłoża dla afektywnych populistycznych reakcji w niemal wszystkich krajach wchodzących w skład unijnej wspólnoty. Choćby w Danii, Irlandii, Holandii, Belgii, Francji, w Czechach i w Polsce „populiści wykorzystali potencjał afektów przeciwko «biurokratom» i ich prawu w/z Brukseli" (Stolleis 2015: 179).

To właśnie stosunek do prawa unijnego ${ }^{3}$, który był tematem niedawnej kampanii przed wyborami do parlamentu w Polsce oraz wyborami do Parlamentu Europejskiego (październik - maj 2019), stanowi jeden z przykładów bardzo charakterystycznej dla ostatnich lat ambiwalencji polskich obywateli. W dość powszechnym odczuciu Polaków ambiwalencja ta jest jednym z największych kryzysów, jaki dotyka Polskę. Niektórzy twierdzą, że jest za ten kryzys odpowiedzialna, a inni, że po prostu jest jego efektem.

Krótko po jednych i drugich wyborach, wygranych przez polityczną opcję kontestującą prymat unijnych przepisów nad krajowymi, przeprowadzono u nas najnowsze badania opinii w ramach Eurobarometru. Okazało się, że nawet bardzo ostry w przebiegu konflikt polityczny wokół niezależności sądownictwa nie spowodował, że obywatele Polski przestali czuć się unijnymi Europejczykami. Robert Sobiech z Centrum Polityki Publicznej w Collegium Civitas, porównując Polskę z innymi krajami, komentuje:

Przeważająca większość Polaków nie wyobraża sobie życia poza Unią Europejską. 81 proc. badanych postrzega siebie jako obywateli Unii Europejskiej, zaś 71 proc. badanych czuje się związana z Unią Europejską. To znacząca zmiana w porównaniu z sytuacją sprzed kilku lat. W 2013 roku tylko 67 proc. badanych czuło się obywatelami Unii. Pozytywny stosunek do Unii Europejskiej ujawnia się szczególnie wyraźnie w porównaniu z poglądami badanych z innych państw członkowskich. Polacy należą do społeczeństw najsilniej identyfikujących się z Unią Europejską. Wyraźnie odróżniają się np. od Holendrów, Finów czy Czechów, spośród których mniej niż połowa deklaruje związek z Unią Europejską. Unia Europejska wywołuje pozytywne emocje u 50 proc. Polaków. U naszych południowych sąsiadów (Czechy, Słowacja), także we Francji, Austrii czy Hiszpanii pozytywne skojarzenia z UE deklaruje natomiast około $1 / 3$ badanych. Jedynie u 9 proc. badanych Polaków Unia wywołuje skojarzenia negatywne. Niższy poziom negatywnych emocji odnotowano jedynie w Irlandii i na Litwie (Sobiech 2020).

3 Chodziło o ostry konflikt polityczny dotyczący niezależności polskiego sądownictwa. 
Tego typu deklaracje bynajmniej nie znoszą problemu wspomnianego dwuwartościowania. Doskonale widać je na przykład w rozbieżnym definiowaniu najważniejszych problemów Unii i Polski; panuje ogromny rozdźwięk choćby w odniesieniu do imigracji - kryzys migracyjny jest ważnym problemem Unii, ale już - wg ankietowanych - jakoby nie Polski. Socjolog tylko sygnalizuje w swoim komentarzu, że w Polsce (i w krajach o podobnej historii) społeczny opór wobec sposobów rozwiązywania problemów, z jakimi zmaga się Unia Europejska, może mieć także inne przyczyny. Jakie?

\section{3. „Polsce szło dobrze”}

Cofnijmy się teraz w czasie do roku 2016, kiedy sytuacja polityczna w Polsce zmieniła się na tyle, że komentator i współwłaściciel niemieckiego tygodnika „Der Spiegel” pisał:

W rzeczywistości trwa wojna kulturowa między Wschodem a Zachodem. I przyszedł czas na gorzkie rozpoznanie: zachodnie wartości liberalizmu, tolerancji i równości przeciwstawiają się wschodniej niegodności - rasizmowi, ignorancji, ciasnocie umysłowej.

I dodawał: „Najpierw Węgry, teraz Polska. Europa Wschodnia coraz bardziej upodabnia się do Rosji: autorytarnej, ograniczonej, rasistowskiej” (Augstein 2016).

Co zaszło w Polsce z końcem 2016? Przypomnę krótko i hasłowo: To wtedy miała miejsce sekwencja burzliwych wydarzeń w sejmie - planowano ograniczenia pracy dziennikarzy, wykluczono z obrad posła opozycji, a po blokadzie mównicy w sali plenarnej przeniesiono obrady do innej sali, by tam przegłosować budżet na kolejny rok, a także tzw. ustawę dezubekizacyjną. Wydarzenia tamtego czasu trafiły do internetowej encyklopedii pod hasłem „kryzys sejmowy w Polsce" i zaowocowały, z jednej strony, rozlicznymi komentarzami i analizami, z drugiej zaś - dużym niepokojem społecznym. Niemiecki dziennikarz podsumowuje: „Krótko po świętach weszła w życie [w Polsce - M.Z.W.] ustawa, która wyrywa zęby trybunałowi konstytucyjnemu, a chwilę przed tym uchwalono inną, odbierającą niezależność mediom publicznym” (Augstein 2016). Jego tekst jest krótki i emocjonalny, utrzymany w poetyce autorskiego komentarza, ukazał się zresztą w weekendowym wydaniu online. Uwagę zwraca ton wypowiedzi - komentarz pisany jest na ostro i gorzko - ale też zastosowana rama komunikacyjna. Jakob Augstein bowiem pisze i myśli postkolonialnie. Dyskurs postkolonialny w kontekście polsko-niemieckim i niemiecko-polskim nie jest bynajmniej niczym nowym. Zasilały go rozbiory, II wojna światowa, powojenny 
podział Europy na radziecki Wschód i wolny Zachód, a reanimował choćby upadek muru berlińskiego. Wbrew pozorom to na początku lat dziewięćdziesiątych $\mathrm{xx}$ wieku odżyły bowiem z nową mocą „dawne imagologiczne podziały” (Kledzik 2013: 19) na centrum i prowincję ze wszystkimi ich dyskursywnymi atrybutami w postaci oświeconych i zacofanych, tzn. lepszych i gorszych Europejczyków. Niemniej w stanie badań tę (auto)narrację mądrzejszego Niemca wobec nieukształtowanego albo źle ukształtowanego Polaka, ewentualnie uwodzącej urodą Polki, dość rzadko wpisuje się wprost w paradygmat postcolonial studies (Zduniak-Wiktorowicz 2018; Uffelmann 2020).

Co ciekawe, ujmowanie Polski przez Jakoba Augsteina w duchu postkolonialnej wyższości rozwarstwia się w jego komentarzu na tyle, że Polakom przypisani zostają tu aż dwaj hegemoni. Jednym jest Rosja, do której Europa Wschodnia, chce czy nie, coraz bardziej się upodabnia: „Polacy mogą bać się i nienawidzić Rosjan - ale tak naprawdę powinni się z nimi dobrze dogadywać. Polska nowego prawicowego rządu coraz bardziej przypomina Rosję Putina" (Augstein 2016). Drugą siłą, wobec której Polska musi się określać - ale nie daje rady - są Niemcy, jej zachodni sąsiad, a jednocześnie stary kraj Unii. Choć w tym drugim aspekcie przekaz nie jest tu bezpośredni, dotyczy stale obecnej w bilateralnym, polityczno-społecznym dyskursie Niemiec i Polski jako sąsiadów (ale też w naszym krajowym dyskursie) opowieści o powrocie.

Chodzi, rzecz jasna, o powrót Polski do Europy, tożsamy z jej wstąpieniem do Unii Europejskiej (z perspektywy polskiej). Jest to jednak też opowieść o wprawdzie przyspieszonej, ale dobrze odrabianej przez nas lekcji zachodnich wartości - na czele $\mathrm{z}$ bezpośrednią demokracją, postrzeganą jako dobro nadrzędne (perspektywa niemiecka). W interesującym mnie stanie badań, na który składają się opracowania naukowe i teksty publicystyczne, bardzo często pojawia się określenie „wzorowy uczeń” (niem. Musterknaben), które ma oddawać zapał i talenty Polaków w nadrabianiu zaległości po przyjęciu Polski do Unii Europejskiej. Takim określeniem posługuje się też w swoim reportażu Smechowski. Zgodnie z jej źródłami i wiedzą Polska uchodziła za przykład „europejskiej historii o sukcesie”, była „prymusem pośród państw członkowskich UE", a kiedy w świecie zaczął się kryzys finansowy, biła po oczach wzrostem gospodarczym. Dodawszy do tego rok 1989 i pierwszeństwo w obalaniu komunizmu przez Polaków, autorka mogła podsumować to wyliczenie tylko w jeden sposób: „Polska miała się dobrze” (Smechowki 2019: 13).

Warto w tym miejscu jednak przypomnieć, iż nasze przejście od komunizmu do demokracji tak naprawdę polegało jednak na westernizacji. Badania prowadzone w nurcie tranzytologicznym (w latach dziewięćdziesiątych paradygmat ten zagościł w polskiej nauce zajmującej się kwestiami przeobrażeń 
Polski i jej mieszkańców) przypominają, że na Zachodzie, czyli tam, dokąd chciano dojść po uwolnieniu się z twardego ucisku komunizmu, czekała Europa „właściwa”. Ważna była też wspomniana narracja o powrocie: „niewłaściwa” Europa Środkowo-Wschodnia zmierzała w jej kierunku i jednocześnie wracała do niej po długiej przerwie. Powrót ten w dyskursie społecznym zasadzał się na odtwarzaniu spojrzenia Zachodu jako hegemona łaskawego, przychylnego nam mimo wszystko (tzn. mimo naszej wschodniości traktowanej też jako stan chorobowy). Co ważne, ten drugi aspekt dyskursu uwewnętrzniła polska racja stanu, chcąc sobie dodać animuszu i upewnić się w swoim, najwyraźniej dla niej samej niepewnym, projekcie przyspieszonego stawania się Europą „właściwą”, tzn. racjonalną, postępową, godną zaufania, zasługującą na szacunek.

Tak przedstawiał się dyskurs przejścia Polski na nowe, ale znane jej z historii pozycje po 1989 roku - jak pokazuje Jan Grzymski w rozprawie Powrót do Europy - polski dyskurs. Wyznaczanie perspektywy krytycznej (Grzymski 2016). W kontekście Polski i Niemiec, które były później adwokatem przyjęcia nas do wspólnoty europejskiej, warto więc zauważyć, że dyskurs powrotu do Europy zapoczątkowany rokiem 1989 odbywał się w specyficznych, nieprzezroczystych warunkach, jakie to sąsiedztwo współtworzyły i nadal współtworzą. Książka politologa zaczyna się od fragmentu przemówienia wygłoszonego przez Aleksandra Kwaśniewskiego na krótko przed wstąpieniem Polski do Unii Europejskiej. Badacz prezentuje ten tekst jako jeden $z$ wielu zebranych przezeń przykładów „szantażu Europą”:

Kwaśniewski przede wszystkim gratulował Polakom niepodległości, demokracji, rządów prawa. Przedstawił to jako „fundament naszej drogi ku Europie”. Z jednej strony podkreślał, że „w europejskiej wspólnocie uczestniczymy przecież od Mieszka I i Bolesława Chrobrego”, ale z drugiej strony, o okresie od 1989 roku do 2004 roku, mówił jako o „egzaminie z europejskości”. Stanęliśmy do niego - zdaniem Kwaśniewskiego - z własnej, nieprzymuszonej woli. „Zdaliśmy! - entuzjazmował się - I dziś jesteśmy już razem. Razem ze zjednoczoną Europą. [...] Oto dziś Polska wraca do europejskiej rodziny. Polki, Polacy, Europejczycy - witajcie we wspólnej Europie" (Grzymski 2016: 11).

Powidoki takiego ujęcia odnajduję u Emilii Smechowski, która, chcąc nie chcąc, traktuje Polskę jako miejsce bardzo starające się o to, żeby Europą być. Tym bardziej, że europejskość już nawet się Polsce udawała, przecież Polakom „już tak dobrze szło” - taki jest koncepcyjny punkt wyjścia autorki. Widać więc, że w narracji Rückkehr nach Polen ożywa nie tylko ta właściwa Niemcom 
i sąsiedzkiemu dyskursowi opowieść o osiągniętej normalizacji stosunków, ale też o uprzednim osiągnięciu stanu normalności przez Polskę:

Zaczęło się tak dobrze z tym krajem. Trzydzieści lat temu Polska emanowała mocą zjednoczenia Europy, jak żaden inny kraj walczyła o wolność i demokrację. Teraz świat Polski już nie rozumie. Sami Polacy też siebie niekoniecznie rozumieją (Smechowski 2016: 9).

Motyw szantażowania europejskością w pełni odżywa jednak w tekście Augsteina - pisanym ponad dziesięć lat po wejściu Polski do Unii Europejskiej - gdy autor nawiązuje do koncepcji tzw. Europy i Unii różnych prędkości. Oto Zachód, Niemcy - wyrażone tu m.in. poprzez użycie czasowników w 1. osobie liczby mnogiej - zastanawiają się, czy Europa aby na pewno ma tyle czasu, żeby czekać na skuteczne zmodernizowanie się spóźnialskich (Polski i Węgier). A może po prostu - pisze dziennikarz - „Potrzebujemy nowej Unii - bez Wschodu?” (Augstein 2016). Oprócz diagnoz zapóźnienia i jego bulwersujących autora skutków w postaci autorytarnych zapędów polskiego rządu pojawia się też w jego argumentacji znany motyw niedojrzałości, braku gotowości Polaków do odpowiedzialnego funkcjonowania w strukturach Unii. Mocno brzmią w tekście słowa Jacques'a Delorsa, byłego przewodniczącego Komisji Europejskiej, który przed laty miał przestrzegać najważniejszych unijnych polityków, że przyjęcie nowych członków ze Wschodu to błąd, bo żaden kandydat nie był na to gotowy. Autor dodaje: dziś wiemy, że to prawda - w przypadku Polski i Węgier na pewno.

Smechowski, niegdysiejsza emigrantka z Polski do Niemiec, młoda autorka zaangażowana pisarsko w swój migrancki status, a co za tym idzie w sprawy niemiecko-polskie, w Rückkehr nach Polen również napisze o wydarzeniach, które tak wzburzyły Augsteina, i to zaraz na początku swojej relacji: „Pis przeforsował nowe ustawy na nocnych posiedzeniach sejmu” (Smechowski 2019: 14). Gromadząc fakty dla niemieckich odbiorców, informuje też o zmianach kadrowych, jakie za nowej władzy następowały a to wśród sędziów różnego szczebla, a to w szeregach dziennikarzy pracujących w państwowej telewizji, ale też o zmianach w szkolnictwie powszechnym i programach nauczania. Wszystkie te fakty to, według niej, „,cofnięcie się do tego, co narodowe”, w którym Polska zresztą przoduje, niczym ,jakaś awangarda” (Smechowski 2019: 14).

Choć ów sprawozdawczy ton, udanie zresztą hamujący odautorską ironię, wzmacniają też w reportażu wątki osobistych rozmów z Polakami w Polsce (rodzina, nowi znajomi) o tym, czym „dobra zmiana, gute Wechsel” jest u podstaw, to dla naszych rozważań szczególnie ciekawa jest wschodnio-zachodnia rama myślowa, jaką autorka stosuje. Robi to w dwojaki sposób. Po pierwsze, 
Smechowski odwołuje się do nośnego z różnych przyczyn, utrzymującego się u nas podziału na Polskę A i B, który pomaga jej w uproszczony sposób zobrazować kolejny podział - na wyborców Po i wyborców Pis-u. Wschód Polski stanowi dla niej także niemal granice Europy - to znany motyw w niemieckim reportażu; tak opisywał świat po wschodniej stronie Niemiec choćby Wolfgang Büscher w książce Berlin - Moskwa. Podróż na piechotę (Büscher 2004). Po drugie jednak zewnętrzna matryca West - Ost służy Smechowski do zaznaczenia horyzontu myślowego jej samej jako piszącej, ale też jej czytelników. Na czym polega to ujęcie, dobrze pokazuje jeden ze wstępnych akapitów reportażu:

Być może, jak sądzę, Zachód przez długi czas nie chciał dostrzec szczeliny na Wschodzie. Tak jak zasadniczo bardzo niechętnie patrzy na Wschód. Zachód boi się spojrzeć na Wschód, bo nie wie, czy zobaczy tam swoją przeszłość, czy przyszłość - powiedział mi kiedyś znajomy. To go niepokoi, więc lepiej, żeby odpuścił. Myślę, że jest w tym trochę prawdy. Wygodniej było nie patrzeć uważnie i opowiadać historię polskiego sukcesu, bez sprzeczności, bez problemów. Teraz już się tak nie da (Smechowski 2019: 14).

Książka o jej pobycie w Polsce uzmysławia, że autorka - mimo iż czuje się w jakimś sensie rozdarta - jest z Zachodu: stamtąd, gdzie porządnie segreguje się śmieci i zwraca zużyte plastikowe butelki po napojach. Szereg obserwacji, które skłaniają mnie do tego stwierdzenia, odnajdziemy nie tylko w doborze argumentacji, zapisach jej reporterskich rozmów z Polakami (zdarzają się też ewidentne wpadki, którymi podbija wschodniość - jak ta, że na Podlasiu pije się wódkę do śniadania o szóstej rano ${ }^{4}$ ), ale też - i to jest nowa jakość w niemiecko-polskiej prozie migranckiej - w zajmującym połączeniu polityczności z prywatnością, nieprzefiltrowanym przez fikcję literacką. Reportaż pomyślany został bowiem jako zapis prób odnalezienia się w Polsce autorki z jej nabytą przecież niemieckością (socjalizacja, mentalność, doświadczenia), ale też jako matki, która na rok zabrała do Gdańska kilkuletnią córkę. Niemal każdej z tych prób towarzyszy poczucie niedopasowania do Polski. Wyraźnie widać, jak narracja balansuje między potrzebą zachowania obiektywizmu reporterki a wyrażeniem bardzo niekiedy przykrych i intymnych odczuć związanych z wymagającym dla matki i córki doświadczeniem socjalizacji tej drugiej w polskim przedszkolu. Spod pióra Smechowski wyłania się siermiężna pod wieloma względami reality

4 Ostrą krytykę książki Smechowski sformułował Peter Oliver Loew, pisząc o błędach i półprawdach, jakie, jego zdaniem, zawiera omawiany reportaż (Loew 2019). 
(ponad miarę grodzone place zabaw), odzwierciedlająca polską mentalność, która potrafi ranić: personel przedszkola nie rozumie sytuacji cudzoziemskiego dziecka, które uczy się polskiego, panuje wszechobecny klimat konkurencji, a nie zachodniego współdziałania. Mentalność ta zaskakuje nie tylko reporterkę, ale też matkę. Doskonale pokazuje to scena w przedszkolu, którą warto w tym miejscu streścić: jest okres wielkanocny, w przedszkolu zaaranżowane zostało przedświąteczne spotkanie $\mathrm{z}$ występami, po których rodzice mają $\mathrm{z}$ dziećmi przystroić wielkanocne koszyki. Wszyscy uśmiechnięci siedzą przy małych stolikach, po czym w odpowiednim momencie zaczynają się prace nad koszykami. Smechowski pisze: „Nie rozumiem, w co się tu gra, ale sytuacja przypomina mi zawody" (Smechowski 2019: 60). Okazuje się bowiem, że w odróżnieniu od reszty rodziców nie przyniosła ze sobą żadnych dekoracji, elementów do upiększenia koszyka. Nie wiedziała, że powinna. Później jest tylko gorzej: polskie dzieci i ich polscy rodzice przy sąsiednich stolikach widzą, że Smechowskie nie mają ze sobą żadnych materiałów, a rozżalona dziewczynka płacze. Nikt jednak nie reaguje, nie podrzuca wstążeczki ani bibuły. Każda rodzina z zapałem i w skupieniu na sobie ozdabia swój koszyk.

Polsko-niemiecka/niemiecko-polska twórczość migrancka jest bogata w afekty (Makarska 2016) i z pewnością może stanowić pokaźny rozdział alternatywnej historii literatury polskiej czytanej na nowo przez ich pryzmat - co retorycznie sugerował Przemysław Czapliński w artykule Poetyka afektywna i powieść o rodzinie (Czapliński 2015). Ograniczając się w tym miejscu tylko do zasygnalizowania kwestii afektywności jako bogatej sfery znaczeń polskiej i niemieckiej, ale związanej z Polską literatury w Niemczech, wskażę na zauważalne w niej przesunięcie: o ile proza generacji, którą reprezentuje Helbig (należą do niej m.in. tacy prozaicy, jak Janusz Rudnicki, Krzysztof Niewrzęda, Dariusz Muszer), autoironicznie i po polsku rozprawiała się z okupacyjnymi krzywdami, emigranckimi upokorzeniami, jakich emigranci w latach osiemdziesiątych xx wieku doznawali w obozach dla przesiedleńców, utratą męskości, o tyle jej generacyjna następczyni, młoda niemiecka proza (w tej roli grupa reprezentowana przez Smechowski, ale też Matthiasa Nawrata, Alexandrę Tobor, Alice Botę), odkrywa polskość - zarówno dla niemieckiej literatury, jak i dla samej siebie. Dzieje się tak dlatego, że w wielu przypadkach rodzice tych autorów - ostatni emigranci z przedprzełomowej Polski - nie chcieli polskości pielęgnować, a niekiedy wręcz w ogóle ujawniać - taka jest oś narracyjna poprzedniej książki Smechowski pt. My, super imigranci (2018). Autorka pokazuje w niej, że Polacy w Niemczech stanowią tę migracyjną społeczność, która $z$ różnych przyczyn jest niewidzialna. Dlatego też pisanie o Polsce przez młode pokolenie autorek i autorów i de facto o ich polskim pochodzeniu 
możemy traktować jako coming out - takim określeniem posłużyła się ostatnio Helbig-Mischewski (Helbig-Mischewski 2019). Jeśli chodzi o kształt gatunkowy tych „wyoutowanych” tekstów, warto dodać, że w istocie powtarzają się wśród nich opowieści o rodzinie, tj. o polskiej rodzinie w Niemczech. Krąg rodzinny zaś, jak wiadomo, stanowi przestrzeń wielu codziennych afektacji, które status migrancki wydatnie wzmacnia.

Ponieważ w tym artykule przyglądamy się kontekstom wystąpień dwóch wybranych autorek, chciałabym krótko wskazać na jeszcze jedno ich wspólne miejsce. Otóż Helbig-Mischewski w przywołanym artykule o coming outcie do tej wspólnoty ujawniających się twórców bezpośrednio dopisała samą siebie, choć równolegle zaznaczyła też dystans - znów jako badaczki, ale też pisarki o długim artystycznym stażu w Niemczech. Niech tę postawę zobrazują dwa cytaty:

Polacy wychodzą z cienia. Nagle uświadamiają sobie: dlaczego, do diabła, tak się ukrywaliśmy przez cały ten czas? Czego, u licha, baliśmy się, że tak się kamuflowaliśmy? Dlaczego za wszelką cenę chcieliśmy się asymilować, być niewidzialnymi? (Helbig-Mischewski 2019: 123).

O ile w tym fragmencie znajdujemy emocjonalne autobiograficzne „my”, w drugim widać już podkreślenie perspektywy uczestniczącej badaczki:

Świadectwa literackie i analizy naukowe (ale także moje codzienne doświadczenia) potwierdzają, że migrantów przybywających do Niemiec z Europy Środkowo-Wschodniej, Turcji czy krajów arabskich zbyt często męczy wstyd. Podczas dyskusji panelowej w Collegium Polonicum w Słubicach (na konferencji „Doświadczenia migracyjne we współczesnej Europie”, zorganizowanej przez Małgorzatę Zduniak-Wiktorowicz i mnie) Matthias Nawrat, Alexandra Tobor i Paulina Schulz opowiadali o tym, jak na ulicy wstydzili się rozmawiać po polsku z rodzicami. Mnie samą latami męczył koszmar senny, w którym głośno mówiłam po polsku przy kasie w supermarkecie w Niemczech (Helbig-Mischewski 2019: 126).

Jeśli na tym problemowym tle (tematyzowany w tej twórczości dyskomfort związany z pokonywaniem migracyjnego wstydu i lęku o to, że się zostanie zdemaskowanym jako Polka czy Polak) spojrzeć na aktywności obu pisarek, które tłumaczą Niemcom Polskę, łatwo zauważyć, że polska literatura w Niemczech przeszła długą drogę (Helbig-Mischewski, Zduniak-Wiktorowicz 2015). 


\section{Jeszcze nie „Kulturkampf”}

To, co dla Smechowski podróżującej po Polsce może być nowe i dziwne, gdy chodzi o zachowania Polaków, raczej nie zaskakuje więc Helbig, która funkcjonuje na co dzień w obu kulturach. Mając świadomość ich różnic, postanowiła zareagować właśnie na przywoływany już tekst Augsteina i ogólną gęstniejącą wówczas w Niemczech krytyczną atmosferę, poprzetykaną stereotypami i uproszczeniami w odniesieniu do Polski. Pisarka, która od lat mieszka i pracuje w Berlinie, ale pracuje też w Szczecinie czy Poznaniu, będąc z wykształcenia polonistką i kulturoznawczynią, twierdzi, że bycie imigrantką stwarza „fantastyczną możliwość przeżywania obcej kultury od wewnątrz" (Helbig-Mischewski 2002: 75). Sytuacja życiowa, ale na pewno też profil wykształcenia, które pozwalają unikać etnocentryzmu i krytycznie, nie-swojo spoglądać na kulturę polską i niemiecką z tej wyjątkowej interkulturowej perspektywy, to według autorki Aniołów i świń. W Berlinie! pisarski luksus. Interkulturowość jako status pisarski nie polega jednak w tym przypadku tylko na funkcjonowaniu w obu kulturach, ale przekłada się też na syntetyzowanie doświadczenia tych kultur i zabieranie na ten temat głosu z pozycji meta - wyznaczanej przez kulturowy styk czy nawet tworzący się margines. W tym ujęciu granice ustępują miejsca pograniczom jako stylowi myślenia i działania i nie służą dzieleniu czy separowaniu, ale włączaniu lub wymianie. Taka epistemologia pograniczy bliska jest m.in. zagadnieniom postkolonialnej tożsamości, a w jej obrębie dochodzeniu sprawiedliwości przez stłamszony podmiot, ale też umacnianiu nowej wspólnoty (Domańska 2012: 89). Zgłębiając specyfikę owej epistemologii, Ewa Domańska zadaje sobie jako badaczce aktywnej w tym nurcie pytania, które doskonale charakteryzują też sytuację pisarki i badaczki Helbig, po części również sytuację pisarki i reporterki Smechowski, a także oddziaływanie obu ich wystąpień zaangażowanych w niemiecko-polski problem:

Czy podejmując badania nad zagadnieniami pogranicza [rozumianego dyskursywnie -M.Z.W.], gdzie jednostki [...] walczą o rozpoznanie [...], identyfikuję się z tzw. humanistyką walczącą, krytyczną, interwencyjną? Dlaczego podejmowany temat badawczy jest dla mnie ważny? Czy jako badacz - należę do tej grupy i występuję w jej imieniu? Czy opowiadam się po stronie badanych grup [...]? Na jakie potrzeby odpowiada ten temat badań? I jaka jest jego wartość dla na przykład budowania społeczeństwa demokratycznego, wielokulturowego; promowania idei wspólnotowości i poszanowania inności? Czy taka wiedza włącza się w proces budowania demokracji partycypacyjnej czy agonistycznej? (Domańska 2012: 89). 
Obie czytane tu przez nas autorki tekstów o Polsce, będąc pisarkami, wchodzą też w rolę badaczek - Helbig jako akademiczka (jej domeną jest kwerenda), a Smechowski jako reporterka (jej domena to research). Czy to więc w sposób naukowy, czy dziennikarski opisują swoje przedmioty badawcze, jednocześnie należąc do opisywanych przez siebie grup: Niemców i Polaków. Jak wiadomo, z dzisiejszej perspektywy humanistyki zaangażowanej jest to pozycja uprzywilejowana, gdy idzie o zabranie głosu.

W interesującym nas artykule, który ukazał się w „Die Zeit” pod przywołanym na wstępie tytułem Kto bezmyślnie beszta Polskę, najwyraźniej niewiele zrozumiał, Helbig występuje z pozycji znawczyni obu kultur, jednak bierze na siebie funkcję przedstawicielki tych, których się nie rozumie: „Wielu ludzi nie wie, co teraz myśleć o Polsce, która w ostatnich latach była przecież takim unijnym prymusem" (Helbig-Mischewski 2016). Po czym objaśnia jak rasowy mediator. W sytuacji kryzysowej, po latach tzw. normalizacji stosunków niemiecko-polskich chce zabrać głos, ponieważ wie więcej - dobrze zna historię i mentalność obu stron tej wadliwej komunikacyjnie sytuacji. Jak wiadomo, sposobem budowania wiedzy jest język komunikacji. To na nim skupia uwagę autorka, wczytując się w sformułowania Augsteina i raz po raz spiesząc z dydaktycznym uświadomieniem:

Nie mieliśmy do czynienia $\mathrm{z}$ „zamachem stanu”, pis doszedł do władzy w sposób demokratyczny. Termin „objąć dozorem” przypomina niestety czasy okupacji z II wojny światowej, a określenie „Kulturkampf” Ottona von Bismarcka i czasy rozbiorów Polski przez Prusy, Rosję i Austrię, ale też okupację i agresywną politykę germanizacyjną (Helbig-Mischewski 2016).

Jednak w jej wystąpieniu oprócz wskazania na krzywdzący i nieadekwatny język, jakiego używa się w Niemczech do opiniowania sytuacji w Polsce, pojawia się też wiele faktów mających zobrazować Niemcom stan polskiego ducha i jego skutki - wygraną w wyborach partii, której prawicowe rządy upodabniają Polskę, jak chciał Augstein, do Putinowskiej Rosji. Tekst Helbig, jego objaśniająca dykcja i dobór słownictwa jednoznacznie pokazują, że wschodni sąsiad nie jest Niemcom bliski - bliskość bierze się bowiem z wiedzy, znajomości partnera. Dlatego autorka zabiera czytelników w przeszłość, pokazując jej zagmatwane niuanse, jak np. znaczenie i forma polskiego patriotyzmu. W tym celu niemiecki odbiorca dostaje podręczny zestaw faktów z polskiej historii - 120 lat niebytu państwowości, potem II wojna światowa, a potem długi okres sowieckich wpływów. Skutkiem tego - rekonstruuje fakty Helbig - po roku 1989 „Polska 
nie nacieszyła się swoim odzyskanym państwem na tyle, żeby z niego chętnie zrezygnować” (Helbig-Mischewski 2016). Tymi historycznymi obciążeniami tłumaczy Niemcom potrzebę głoszenia suwerenności, wyrażania sprzeciwu wobec „nie swoich wartości”, wyczulenie na podleganie wpływom, wreszcie powoływanie się na chrześcijańskie sumienie jako tożsame z wartościami narodu i patriotyzmem. To one pozwalały bowiem Polakom na przestrzeni wieków formować opór, a w efekcie wygrać walkę o pełną suwerenność: „Polska nie przetrwałaby bez patriotyzmu" (Helbig-Mischewski 2016).

W swoim wywodzie autorka Enerdowców i innych ludzi nie tylko prześwietla przeszłość, ale pokazuje też te postzależnościowe skutki jej trwania, jakie jej zdaniem unaoczniają przyczyny społecznego poparcia w Polsce polityki prawicowych konserwatystów: jest tu mowa o zaniedbaniach Po, gdy idzie o poczucie ekonomicznego wykluczenia pewnych warstw społecznych: „W dużych miastach było jednak również wielu emerytów i starców, żyjących na granicy ubóstwa i wychowanych w duchu patriotycznym sprzed 1989 roku. Nie czuli się reprezentowani przez poprzedni rząd, raczej zaskoczeni, a nawet zdradzeni” (Helbig-Mischewski 2016) ${ }^{5}$. Dokładnie te same argumenty znajdujemy też u Smechowski. Autorki wyraźnie różni jednak podejście: podczas gdy Helbig-Mischewski jest w swoim pisaniu empatyczna, stosunek Smechowski do Polski jest nieoczywisty. Sądzę, że pokazuje to też sam ekspedycyjny podtytuł jej książki.

\section{Rozłam, Spaltung, rysa, rów}

Rozłam społeczny (niem. Spaltung) w artykule Helbig i analizie Ruchniewicza traktowany jest jako widzialny objaw kryzysu wartości w Polsce, ale też dyskursywne domniemanie podstaw tego kryzysu. Podobnie pisze o sytuacji w swym dawnym „Heimatlandzie” Smechowski. Użyty przez nią synonim rozłamu ma jednak dużo bardziej literacki charakter - jest tu bowiem mowa o rysie. Symbolizuje ona kryzysową Polskę i tworzy oś narracyjną reportażu. Leksem

5 Na ów aspekt przeoczeń rządów liberałów uwagę zwracają też w Niemczech polscy politolodzy i historycy. Pisał o tym m.in. Krzysztof Ruchniewicz - dyrektor wrocławskiego Centrum Studiów Niemieckich i Europejskich im. Willy’ego Brandta, które jest instytucją wzmacniającą dobre praktyki dialogu polsko-niemieckiego/niemiecko-polskiego. W tekście z 2020 roku zamieszczonym w „Zeitschrift der Bundeszentrale für Politische Bildung" w tonie informowania niemieckich czytelników pisze m.in. o zaniedbaniach liberałów, którzy w obliczu stosunkowo dobrej pozycji Polski podczas kryzysu finansowego w Europie przegapili ludzi niemogących wziąć udziału w sukcesach gospodarczych. Ci zaś czuli się wykluczeni i zapomnieni, a „ich frustracja rosła” (Ruchniewicz 2020: 27). 
„rysa” trafia też na okładkę, gdzie pełni funkcję marketingowego lepu: „Dokąd zmierza kraj, przez który przechodzi głęboka rysa?”.

Wspomniałam o tym, że Smechowski reprezentuje kolejne, póki co najmłodsze, pokolenie autorów biograficznie związanych z Polską, piszących o Polsce w Niemczech. Spod pióra tej generacji dostawaliśmy już i wciąż dostajemy nowe przykłady twórczości, która zyskała uznanie i czytelników właśnie dlatego, że tematyzuje naturę kontaktów polsko-niemieckich/niemiecko-polskich na tle historii obu państw i narodów. Rezonans twórczości takich młodych autorów jak Matthias Nawrat pokazuje, że bynajmniej nie potwierdzają się oczekiwania (sic!), jakie w latach dziewięćdziesiątych formułował wobec Polski niemiecki rynek wydawniczy.

Pisze o tym m.in. germanistka Mirosława Zielińska w tomie o „dorosłym sąsiedztwie Polski i Niemiec” (Zielińska 2011), przyglądając się charakterystycznym obwarowaniom polsko-niemieckiego transferu kulturowego. Jak dowodzi, przełom polityczny z początku lat dziewięćdziesiątych xx wieku był czasem odkrycia nowego-starego-trudnego sąsiedztwa (Zielińska 2011: 377). Wówczas do głosu doszła potrzeba uwolnienia się elit polityczno-kulturalnych w Polsce od jednowymiarowego obrazu Niemców jako sprawców (rola Początku Andrzeja Szczypiorskiego). Z drugiej strony jednak Zielińska mówi o bardzo specyficznej potrzebie, jaką przejawiała w stosunku do Polski niemiecka opinia publiczna. Chodziło o dostarczenie dowodu na gotowość do bycia wiarygodnym partnerem: takim, który przeprowadził głębokie zmiany we własnym jestestwie, a także potrafi „bezstronnie obchodzić się z najnowszą niemiecko-(polsko)-żydowską przeszłością" (Zielińska 2011: 380). Dowód na dojrzałość miała stanowić sąsiedzka literatura, która wtedy w Niemczech uosabiała obcość, naówczas bowiem powojenne pokolenie Niemców nie czuło się w obowiązku do dialogu czy uwewnętrznienia kwestii związanych z kulturową pamięcią sąsiada. Uwagi poświęcone przez autorkę trzystuletniej historii geopolitycznej obu państw układają się w zbiór przyczyn, dla których stosunek Niemców do Polaków można określić jaką geograficzną bliskość, ale mentalnościową obcość.

Potwierdza to zarówno artykuł Helbig, jak i reportaż Smechowski: wciąż trzeba Niemcom objaśniać Polskę, choć interesujące mnie autorki robią to inaczej. Helbig wie i tłumaczy, Smechowski jedzie do Polski, żeby się dowiedzieć. Pierwsza chce pokazać, dlaczego doszło do tego, że w Polsce nastał kryzys demokracji, druga, dlaczego sprawy zaszły tak daleko, że „wielu Polaków nie wierzy już w wolność" (Smechowski 2019: 9). W odróżnieniu od Helbig Smechowski przyznaje, że nie wiedziała wiele o tej rysie, gdy przyjechała do Gdańska, mimo że wszyscy o niej mówili. Niemniej podsumowuje najnowszą historię Polski w jednym akapicie, robiąc to w duchu cytowanych już Ruchniewicza i Helbig. 
I ona pisze o podziale Polaków, wyczuwalnym już od przełomowego 1989 roku, a pogłębiającym się wraz z upływem czasu. Efektem tego podziału były, rekonstruuje autorka, parlamentarne wybory w roku 2015: „A kiedy jesienią 2015 roku Polacy wybrali konserwatywny rząd narodowy, rysa zamieniła się w rów" (Smechowski 2019: 11). Ale podczas gdy Smechowski pisze o różnicach cywilizacyjnych między Niemcami a Polską, a także między samymi Polakami, zdaniem Helbig ludzie w Polsce mieli za mało czasu, by uwewnętrznić liberalny styl życia, typowy dla dobrze sytuowanych ludzi Zachodu. Przyczyny tego stanu rzeczy, a także wyborczy sukces pis-u, to brak poczucia bezpieczeństwa socjalnego, które np. w Niemczech skutkuje liberalnym światopoglądem.

Niezależnie od różnic w doborze argumentów obie pozycjonują się jasno: piszą o niszczeniu demokracji przez rząd Prawa i Sprawiedliwości, a sytuację tę postrzegają jako daleko posunięty kryzys.

\section{| Bibliografia}

Augstein Jakob (2016), Der schlechte Polenwitz, https://tinyurl.com/u8xjwpzz [dostęp: 1.05.2021].

Bielawska Agnieszka (2009), Normalizacja stosunków polsko-niemieckich - proces wciąż trwający?, „Środkowoeuropejskie Studia Polityczne”, nr 3, s. 159-20o.

Brömmel Winfried, König Helmut, Sicking Manfred (2015), Einleitung, w: Europa, wie weiter? Perspektiven eines Projekts in der Krise, red. Winfried Brömmel, Helmut König, Manfred Sicking, Transcript, Bielefeld, s. 7-25.

Büscher Wolfgang (2004), Berlin - Moskwa. Podróż na piechotę, przeł. Renata Makarska, Czarne, Wołowiec.

Czapliński Przemysław (2015), Poetyka afektywna i powieść o rodzinie, w: Kultura afektu - afekty w kulturze. Humanistyka po zwrocie afektywnym, red. Ryszard Nycz, Anna Łebkowska, Agnieszka Dauksza, IBL, Warszawa, s. 372-401.

Domańska Ewa (2012), Epistemologie pograniczy, w: Na pograniczach literatury, red. Jarosław Fazan, Krzysztof Zajas, Wydawnictwo Poznańskie, Poznań, s. $852-868$.

Grzymski Jan (2016), Powrót do Europy - polski dyskurs. Wyznaczanie perspektywy krytycznej, Elipsa, Warszawa.

Helbig-Mischewski Brygida (2002), Być polskim pisarzem w Niemczech [ankieta], „Dekada Literacka”, nr 5-6, s. 75-76.

Helbig-Mischewski Brygida (2016), Wer Polen basht, hat nicht viel verstanden, https://tinyurl.com/gbxv7dy6 [dostęp: 1.05.2021] 
Helbig-Mischewski Brygida (2019), „Ich komme aus Polen“. Migranten-Literatur als "coming out". Emilia Smechowskis "Wir Strebermigranten" vor dem Hintergrund der Prosa anderer polnischer Migranten in Deutschland, „TRANSFER. Reception Studies", t. 4, s. 123-135.

Helbig-Mischewski Brygida, Zduniak-Wiktorowicz Małgorzata (2015), Inne doświadczenia, inna wiedza? Metodologie narodowe i ponadnarodowe a uciekający przedmiot badań. Rozważania na przykładzie bilateralnego projektu „Najmłodsza generacja autorów polskiego pochodzenia w Niemczech”, „Rocznik Komparatystyczny", nr 6, s. 381-393.

Helbig-Mischewski Brygida, Zduniak-Wiktorowicz Małgorzata, red. (2016), Migrantenliteratur im Wandel / Literatura migracyjna w procesie. Junge Prosa mit (nicht nur) polnischen Wurzeln in Deutschland und Europa / Młoda proza (nie tylko) polskiego pochodzenia w Niemczech i w Europie, red. Brygida Helbig-Mischewski, Małgorzata Zduniak-Wiktorowicz, Leipziger Universitätsverlag, Leipzig.

Iwasiów Sławomir (2014), „Skąd się wzięła ta zabawa, nie wiadomo”. „Niebko” Brygidy Helbig jako przykład narracji polsko-niemieckiej, w: Doświadczenie (po)granicza: polsko-niemieckie Pomorze w historii, literaturze, kulturze, red. Paweł Wolski, Pwn, Warszawa, s. 81-96.

Kerski Basil (2002), Partnerstwo po kiczu. Co dalej z polsko-niemieckim sasiedztwem?, „Gazeta Wyborcza”, 24.01.

Liebert Urlike (2019), Europa erneuern! Eine realistische Vision fur das 21. Jahrhundert, Transcript, Bielefeld.

Loew Peter Oliver (2019), Von Fehlern, Halbwahrheiten und schlechter Recherche, https://tinyurl.com/wc2tyv7k [dostęp: 1.05.2021].

Makarska Renata (2016), Im Zeichen des Uneindeutigen. Lässt sich die "zweite Generation" der polnischen Migranten in Deutchland als seine Generation beschreiben?, w: Migrantenliteratur im Wandel / Literatura migracyjna $w$ procesie. Junge Prosa mit (nicht nur) polnischen Wurzeln in Deutschland und Europa / Młoda proza (nie tylko) polskiego pochodzenia w Niemczech $i$ w Europie, red. Brygida Helbig-Mischewski, Małgorzata Zduniak-Wiktorowicz, Leipziger Universitätsverlag, Leipzig, s. 131-141.

Ruchniewicz Krzysztof (2003), Pojednanie - normalizacja - dobre sasiedztwo, w: Polacy i Niemcy. Historia - kultura - polityka, red. Andreas Lawaty, Hubert Orłowski, Wydawnictwo Poznańskie, Poznań, s. 107-118.

Ruchniewicz Krzysztof (2020), Droht der Polexit?, „Zeitschrift der Bundeszentrale für Politische Bildung” 70. Jahrgang, 23-25, s. 25-31. Sobiech Robert (2020), Dla Polaków członkostwo w UE nie ma alternatywy, https://tinyurl.com/sx3jyv2f [dostęp: 1.05.2021]. 
Smechowski Emilia (2015), Ich bin wer, den du nicht siehst, https://tinyurl.com/5e7dmjuj [dostęp: 1.05.2021].

Smechowski Emilia (2019), Rückkehr nach Polen. Expeditionen in mein Heimatland, Hanser, Berlin.

Stolleis Michael (2015), Muss Europa neu begruendet werden?, w: Europa, wie weiter? Perspektiven eines Projekts in der Krise, red. Winfried Brömmel, Helmut König, Manfred Sicking, Transcript, Bielefeld, s. 177-194.

Thiel Torsten (2015), Die Krise der Demokratie in Europa - und die Krise der Erforschung dieser Krise, w: Europa, wie weiter? Perspektiven eines Projekts in der Krise, red. Winfried Brömmel, Helmut König, Manfred Sicking, Transcript, Bielefeld, s. 101-123.

Uffelmann Dirk (2020), Polska literatura postkolonialna. Od sarmatyzmu do migracji poakcesyjnej, Universitas, Kraków.

Zduniak-Wiktorowicz Małgorzata (2018), Filologia w kontakcie. Polonistyka, germanistyka, postkolonializm, Wydawnictwo UAM, Poznań.

Zielińska Mirosława (2011), Auf dem Weg vom Monolog im Schatten des Zweiten Weltkrieges zum Polylog der global citizen Kulturtransfer der polnischen Literatur im deutschsprachigen Raum, w: Erwachsene Nachbarschaft. Die deutsch-polnischen Beziehungen 1991 bis 2011, red. Dieter Bingen i in., DPI, Wiesbaden, s. 377-392.

\section{| Abstrakt}

MaŁgorZata Zduniak-WikTorowicZ

O systemach wartości, zaangażowaniu i objaśnianiu Niemcom kryzysowej Polski przez polsko-niemieckie pisarki z Berlina: Brygidę Helbig-Mischewski i Emilię Smechowski

Artykuł traktuje o motywacjach i sposobach pisarskiego zaangażowania w relacje polsko-niemieckie autorek, które pochodzą z Polski, tworzą w Berlinie, ale reprezentują różne generacje twórców związanych biograficznie z Niemcami i Polską (Brygida Helbig-Mischewski, Emilia Smechowski). Twórczości te i towarzyszące im aktywności w przestrzeni publicznej w obu krajach (zabieranie głosu w największych mediach) pozostają w ścisłym związku z okołobrexitowym kryzysem wartości w Europie.

Słowa kluczowe: kryzys; Niemcy; Polska; literatura migracyjna; dyskurs 


\section{| Abstract \\ MaŁgorzata Zduniak-Wiktorowicz \\ On Value Systems, Commitment and Explaining Poland in Crisis to Germans by Polish-German Writers from Berlin: Brygida Helbig-Mischewski and Emilia Smechowski}

This essay discusses motivations and various strategies of artistic involvement in Polish-German relations on the part of female writers who come from Poland, write from Berlin and represent different generations of writers associated, by way of their biographies, with Germany and Poland (e.g., Brygida Helbig-Mischewski and Emilia Smechowski). Their writings, and modes of public activity that accompany them in both countries (e.g., voicing their positions in mainstream media) are closely related to a pan-European crisis of values triggered by Brexit and its aftermath.

Keywords: crisis; Poland; Germany; migrant literature; discourse

\section{| Biogram}

Małgorzata Zduniak-Wiktorowicz - dr hab., prof. UAM, pracuje na Wydziale Filologii Polskiej i Klasycznej, gdzie prowadzi zajęcia dla cudzoziemców. Zajmuje się głównie polsko-niemieckimi dyskursami, polską literaturą w Niemczech, w tym niemiecko-polską prozą migracyjną, studiami postkolonialnymi i postzależnościowymi. Autorka monografii: Filologia w kontakcie. Polonistyka, germanistyka, postkolonializm, Poznań 2018.

E-mail: mzduniak@amu.edu.pl

ORCID: 0000-0002-8025-3993 